\title{
Studi Penggunaan Analisis Pendekatan Ilmu-ilmu Sosial dalam Penelitian Hadis Metode Syarah
}

\author{
Wahyudin Darmalaksana \\ Jurusan Ilmu Hadis, Fakultas Ushuluddin UIN Sunan Gunung Djati Bandung \\ Corresponding Author Email: yudi_darma@uinsgd.ac.id
}

\begin{abstract}
The purpose of making this scientific article template is to provide general guidance for students of the UIN Sunan Gunung Djati Postgraduate Program in presenting the results of their research and / or ideas in scientific work. The method of presentation in scientific articles should follow the general pattern commonly used in reputable journals, making it easier for authors to submit articles in these journals; writing scientific papers also needs to be adjusted to the scientific discipline that is the author's field of expertise. Journal articles usually use a systematic method consisting of: abstracts, keywords, introduction, methodology, results and discussion, conclusions, acknowledgments, and references. Specifically for abstracts it must contain elements: objectives, methodology, important results / findings, and conclusions; if possible narration / information can be added about the boundaries of research, practical implications, and social implications. Generally the presentation of abstract does not exceed 300 words. With cambrian font 9 and 1 space. Also made abstract in the form of English at the top before abstracting Indonesian.
\end{abstract}

Keywords: Scientific Articles, Systematics, Citation

\begin{abstract}
Abstrak
Tujuan penelitian ini yaitu membahas penggunaan analisis dalam penelitian hadis melalui metode syarah dengan pendekatan ilmu-ilmu sosial. Metode penelitian ini menggunakan jenis penelitian kualitatif melalui studi pustaka dengan menerapkan analisis isi. Hasil dan pembahasan penelitian ini meliputi hadis sebagai subjek penelitian, pengembangan metode syarah hadis, dan penelitian hadis dengan analisis dari pendekatan ilmu-ilmu sosial. Penelitian ini menyimpulkan bahwa penggunaan analisis dari pendekatan ilmu-ilmu sosial sangat terbuka lebar penerapannya dalam penelitian hadis dengan metode syarah. Penelitian ini merekomendasikan pentingnya perumusan model analisis dari pendekatan ilmu-ilmu sosial dalam penelitian hadis secara lebih luas melalui asosiasi ilmu hadis Indonesia.
\end{abstract}

Kata Kunci: Metode syarah hadis, Hadis sosial, Pendekatan ilmu-ilmu sosial, Penelitian hadis

\section{PENDAHULUAN}

Ada ruang pendekatan ilmu-ilmu sosial dalam analisis penelitian metode syarah hadis. Berdasarkan catatan sejarah, rumpun ilmu sosial berkembang di dunia Barat (Hardiyati, 2020). Sedangkan penelitian hadis metode syarah dalam lingkup 'ulum al-hadits (ilmu hadis) merupakan khazanah keilmuan Islam yang berkembang sejak di masa klasik Islam (Sagir, 2017). Sebagaimana dukungannya terhadap keilmuan Islam secara umum (Adibah, 2017), pendekatan ilmu-ilmu sosial telah berperan menguatkan analisis dalam penelitian metode syarah (Muhtador, 2016). Sungguhpun kenyataan ini telah menandai perkembangan penelitian hadis di Indonesia (Anggoro, 2019), namun masih terdapat beberapa pertanyaan dari kalangan peminat ilmu hadis. Dalam hal ini mereka mempertanyakan masa depan penelitian hadis (Abbas, 2019), khususnya di Nusantara (Wahid, 2017), peran pendidikan tinggi Islam (Wahid \& Masri, 2018) dalam menyikapi ragam penelitian hadis (Muhammad Alfatih

* Copyright (c) 2020 Wahyudin Darmalaksana

This work is licensed under a Creative Commons Attribution-ShareAlike 4.0 International License.

Diterima: 21 September 2020; Direvisi: 5 November 2020; Disetujui: 7 November 2020 
Suryadilaga, 2015), pola penelitian hadis (Adriansyah, 2018), dan orientasi penelitian hadis (N. Huda \& Pahrudin, 2018), termasuk profil Jurusan Ilmu Hadis (Muhammad Alfatih Suryadilaga, 2016). Hal ini menuntut penjelasan mulai dari paradigma (Wendry et al., 2018), epistemologi (Taufik, 2020a), dan metodologi (Burhanuddin, 2018) pemahaman hadis dalam konteks kekinian (Muhsin, 2015), yakni berkenaan dengan penelitian hadis metode syarah di pendidikan tinggi Islam (Taufik, 2020b), yaitu dengan menerapkan analisis dari pendekatan dari ilmu-ilmu sosial (Afwadzi, 2016), di mana hal ini dipandang sebagai manisfestasi dari kesarjanaan Barat (M. Zuhri, 2015).

Ditemukan sejumlah penelitian terdahulu berkenaan dengan penelitian hadis melalui pendekatan ilmu-ilmu sosial. Antara lain penelitian tentang perkembangan penelitian hadis sejak masa klasik hingga masa kontemporer (Wahid \& Masri, 2019). Di era kontemporer ini, penelitian hadis mulai dilakukan secara multidisipliner dengan menerapkan analisis dari pendekatan ilmu-ilmu sosial (Afwadzi, 2016). Beberapa peneliti menganjurkan penelitian hadis dengan pendekatan ilmu-ilmu sosial sebagai keniscayaan perkembangan dari ilmu-ilmu sosial yang pasti berimpikasi terhadap kemajuan keilmuan Islam termasuk ilmu hadis (Afwadzi, 2017). Penelitian hadis dengan analisis dari pendekatan ilmu sosial dipandang mampu mengembangkan perspektif hadis menjadi kontekstual $(A w, 2011)$ dan transformatif (Taufik, 2020a). Dari anjuran-ajuran ke arah kontekstualisasi dan transformasi tersebut, berkembanglah pelaksanaan penelitian hadis dengan analisis dari pendekatan ilmu-ilmu sosial (Afwadzi, 2016). Penelitian hadis metode syarah diakui sebagai pintu masuk yang paling akomodatif dalam penerapan analisis dari pendekatan ilmu-ilmu sosial (Taufik, 2020b). Analisis dari pendekatan ilmu-ilmu sosial dalam penelitian hadis metode syarah dilakukan oleh berbagai jenjang kesarjanaan bidang ilmu hadis yang mencakup jenjang sarjana, magister, dan doktor (Lukman, 2017). Meskipun demikian, ada peneliti yang mengkhawatirkan tergerusnya metode syarah hadis era klasik oleh kemajuan ilmu-ilmu lain yang berkembang di era kontemporer (Kurniati, 2020), yang nota bene merupakan manisfestasi dari kesarjanaan Barat (M. Zuhri, 2015). Ada pula yang mengkhawatirkan terbukanya gelombang liberalisasi dari maraknya penelitian living hadis yang syarat dengan analisis dari pendekatan ilmu-ilmu sosial (Salleh et al., 2019). Akan tetapi, arah kebijakan pendidikan tinggi Islam di Indonesia menetapkan pengaturan (regulation) untuk dilakukan pengembangan penelitian transformatif (Tim Penyusun, 2018c). Justru secara spesifik penelitian hadis diarahkan untuk mengembangkan jenis penelitian living hadis (Tim Penyusun, 2018c) dengan pendekatan ilmu-ilmu sosial secara kontekstual (S. Zuhri \& Dewi, 2018). Bahkan, kebijakan pendidikan tinggi Islam mengarahkan pelaksanaan integrasi ilmu antara ilmu agama dan ilmu umum (Tim Penyusun, 2019b), termasuk integrasi (M Alfatih Suryadilaga, 2007). Penelitian ini berusaha melakukan sistesis dari berbagai pandangan seputar penelitian hadis untuk menegaskan analisis metode syarah dengan pendekatan ilmu-ilmu sosial.

Berbagai rujukan dari penelitian terdahulu bermanfaat bagi penyusunan kerangka berpikir penelitian ini. Bagian pembahasan penelitian ini diawali dengan mengemukakan pandangan hadis sebagai subjek penelitian (Soetari, 1994). Secara paradigmatis (Wendry et al., 2018), hadis Nabi Saw. merupakan sumber Islam kedua setelah al-Qur'an (Sy, 2017). Sedangkan secara epistemologis (Taufik, 2020a), hadis Nabi Saw. merupakan subjek pengembangan ilmu hadis (Soetari, 2005). Adapun secara metodologis (Hariono, 2019), ilmu hadis menyangkut perkembangan berbagai metode penelitian hadis (Burhanuddin, 2018), di antaranya takhrij hadis (Qomarullah, 2016) dan syarah hadis (Soetari, 2015). Metode takhrij hadis berperan untuk mengetahui otentisitas hadis apakah sahih (otentik) atau dhaif (tersisolir) dalam posisinya sebagai sumber ajaran Islam (Wazna, 2018). Sedangkan metode syarah hadis (Sulaemang, 2016) berfungsi untuk menjelaskan teks hadis (matan) dalam posisinya sebagai bayan (penjelas) alQur'an (Musa, 2010). Penelitian hadis dengan metode syarah telah berlangsung sejak masa klasik Islam 


\section{Khazanah Sosial, Vol. 2 No. 3 155-166}

Studi Penggunaan Analisis Pendekatan Ilmu-ilmu Sosial dalam Penelitian Hadis Metode Syarah Wahyudin Darmalaksana

(Santosa, 2016). Sebagai sebuah analisis, penelitian hadis dengan metode syarah dibutuhkan suatu analisis secara interdisipliner, multidisipliner, dan bahkan trandisipliner (Taufik, 2020a). Penelitian hadis dengan metode syarah di era klasik telah menerapkan pendekatan interdisipliner secara terbatas (Sy, 2017), hal ini dilakukan melalui metode ijmali, tahlili, dan muqaran (Kurniati, 2020). Adapun penelitian hadis metode syarah dengan pendekatan multidisipliner dari ilmu-ilmu sosial merupakan perkembangan yang berlangsung di era modern (Taufik, 2020b). Bahkan, peminat ilmu hadis diarahkan untuk melaksanakan penelitian dengan pendekatan transdisipliner dalam upaya integrasi ilmu (Afwadzi, 2017). Penguatan analisis dalam penelitian hadis metode syarah dengan pendekatan ilmu-ilmu sosial diharapkan menguatkan masa depan penelitian hadis (Abbas, 2019), khususnya di Nusantara (Wahid, 2017), peran pendidikan tinggi Islam (Wahid \& Masri, 2018) dalam menyikapi ragam penelitian hadis (Muhammad Alfatih Suryadilaga, 2015), pola penelitian hadis (Adriansyah, 2018), dan orientasi penelitian hadis (N. Huda \& Pahrudin, 2018) di Jurusan Ilmu Hadis (Muhammad Alfatih Suryadilaga, 2016).

Berdasarkan paparan di atas, penelitian ini berusaha menyusun formula penelitian, yakni rumusan masalah, pertanyaan penelitian, dan tujuan penelitian (Darmalaksana, 2020a). Rumusan masalah penelitian ini adalah, terdapat penggunaan analisis dalam penelitian hadis melalui metode syarah dengan pendekatan ilmu-ilmu sosial. Pertanyaan penelitian ini ialah, bagaimana penggunaan analisis dalam penelitian hadis melalui metode syarah dengan pendekatan ilmu-ilmu sosial. Tujuan penelitian ini yaitu membahas penggunaan analisis dalam penelitian hadis melalui metode syarah dengan pendekatan ilmuilmu sosial. Penelitian ini diharapkan memiliki implikasi manfaat khususnya bagi para peminat bidang ilmu hadis dalam pelaksanaan penelitian hadis melalui metode syarah dengan menggunakan analisis dari pendekatan ilmu-ilmu sosial.

\section{METODE PENELITIAN}

Metode penelitian ini menggunakan jenis penelitian kualitatif melalui studi pustaka (Darmalaksana, 2020c). Adapun interpretasi data untuk menghasilkan kesimpulan digunakan analisis isi (Hsieh \& Shannon, 2005)..

\section{HASIL DAN PEMBAHASAN}

Hadis dan ilmu hadis merupakan sebuah paradigma. Paradigma hadis dan ilmu hadis dibangun di atas pemikiran Islam (Wendry et al., 2018). Hadis dan ilmu hadis juga merupakan epistemologi. Epistemologi hadis dan ilmu hadis dikonstruksi di atas keilmuan Islam (Taufik, 2020a). Hadis dan ilmu hadis pun diakui sebagai kerangka metodologi yang berperan mengembangkan ilmu hadis berserta cabang-cabangnya (Soetari, 2005).

Secara istilah, hadis dipahami sebagai apapun yang berasal dari Nabi Saw. (Darmalaksana, 2020b), yang meliputi perkataan (qaul), perbuatan ('amal), pernyataan (taqrir), dan lain-lain (Soetari, 1994). Hadis dari perspektif Islam disepakti sebagai sumber ajaran Islam kedua setelah al-Qur'an (Darmalaksana et al., 2017). Dari sisi fungsinya, hadis Nabi Saw. dipahami sebagai penjelas (bayan) al-Qur'an (Adriansyah, 2018). Sebagai ditegaskan pandangan ulama, ayat-ayat al-Qur'an, yang umumnya bersifat mujmal (global), dibutuhkan penjelasan dari hadis yang lebih bersifat konkrit (Thantowi, 1994).

Hadis merupakan subjek ilmu hadis, hal ini dalam pengkajiannya telah mendorong perkembangan ilmu hadis sejak masa klasik Islam (Nufus, 2018). Sejarah perkembangan keilmuan Islam dibagi beberapa tahap (Andariati, 2020), yaitu masa klasik abad 5-6 M., masa pertengahan abad 12-19 M., dan masa modern dari abad 19 M. (Anshori, 2017). Ilmu hadis sendiri adalah ilmu tentang hadis (Soetari, 1994). 
Ilmu hadis dalam pengertian umum disebut musthalah al-hadits, yang dibagi dua, yaitu ilmu riwayah dan ilmu dirayah (Soetari, 2005). Ilmu riwayah membahas sejarah periwayatan hadis mulai disabdakan dari Nabi Saw., disampaikan dari orang ke orang, dan dibukukan dalam kitab-kitab hadis (Soetari, 1994). Adapun ilmu dirayah membahas otentisitas hadis apakah benar berasal dari Nabi Saw. ataukah bukan berasal dari Nabi Saw. (Soetari, 1994). Hingga hadis diketahui statusnya apakah otentik (shahih) ataukah terisolir (dhaif). Apabila shahih maka hadis diterima (maqbul) sebagai amalan Islam, dan bila dhaif maka ia ditolak (mardud) untuk dijadikan amalan Islam (Soetari, 1994). Ilmu hadis mengalami perkembangan menjadi kompleks hingga melahirkan cabang-cabang ilmu hadis (Husnaini, n.d.). Kompleksitas ilmu hadis di antaranya kaidah keilmuan hadis yang menyatakan bahwa hadis dhaif dapat diterima menjadi amalan Islam bila hadis tersebut ditopang oleh syahid dan mutabi (Soetari, 1994). Syahid adalah teks hadis (matan) lain yang menguatkan, sedangkan mutabi ialah sanad (mata-rantai periwayat) lain yang menguatkan dari teks hadis (matan) dimaksud (Mardiana \& Darmalaksana, 2020).

Bagian ini tidak membahas kompleksitas ilmu hadis, tetapi sebagai penegasan tentang perkembangan ilmu hadis. Diketahui ilmu hadis mengalami perkembangan sejak masa klasik Islam (Muhtador, 2016). Di antara perkembangan metodologi ilmu hadis ialah metode takhrij hadis (Soetari, 2015). Suatu metodologi keilmuan hadis untuk meneliti kesahihan (otentisitas) hadis dengan cara mengeluarkan hadis dari mashadir ashliyah yang merupakan kitab-kitab induk hadis (Darmalaksana, 2020d). Penelitian takhrij meliputi kualitas kepribadian (ke-adil-an) dan kapasitas keilmuan (ke-dhabitan) periwayat hadis (Qomarullah, 2016). Penelitian kebersambungan (mutasil) dan keterputusan (munfasi) mata-rantai periwayatan hadis (sanad). Juga penelitian ke-gharib-an dan kecacatan teks hadis. Melalui penelitian hadis dengan metode takhrij maka diketahui kategori hadis sebagai sahih, hasan, dan dhaif (Soetari, 2015).

Selain metode takhrij hadis (Qomarullah, 2016), berkembang pula metode syarah hadis (Sagir, 2017). Metode ini berkembang dengan fungsi untuk memberikan penjelasan terhadap makna dari kandungan teks hadis (Muhtador, 2016). Di masa klasik berkembang metode syarah hadis (Kurniati, 2020) dengan pendekatan ijmali (global), tahlili (kritis), dan muqaran (komparatif). Dalam penelitian hadis dengan metode syarah digunakan pula penelitian internal teks hadis dan penelitian eksternal teks hadis (Sumarna, 2016). Digunakan pula penelitian asbab al-wurud (sebab turun hadis) dalam meneliti konteks dari tekstual hadis (Muin, 2015). Konsekuensinya, di samping hadis dibahas secara tekstual dengan menggunakan ilmu-ilmu kebahasaan, seperti mufradat (kosa kata), mantik, sematik, dan balaghah, juga hadis dibahas secara kontekstual dengan menerapkan pendekatan sebab wurud al-hadis (Sulaemang, 2016). Di era kontemporer, penelitian hadis dengan metode syarah mulai menerapkan analisis dari pendekatan ilmu-ilmu sosial (Taufik, 2020a). Berbagai metode penelitian hadis berkembang sejalan dengan posisi hadis sebagai subjek penelitian.

\section{Syarah Hadis Pembuka Pendekatan Sosial}

Perkembangan penelitian hadis dengan metode syarah telah membuka pintu penerapan analisis dari pendekatan ilmu-ilmu sosial (Taufik, 2020a). Tidak terlalu salah bila dikatakan bahwa perkembangan ilmu hadis di masa klasik Islam ditopang oleh kebutuhan ilmu fiqih (Darmalaksana, 2004). Ilmu fiqih merupakan ilmu pengamalan syariat Islam dari pondasi utama al-Qur'an (Bahammam, 2013). Untuk halhal yang tidak ditemukan ketentuannya di dalam al-Qur'an, maka digunakan hadis sebagai sumber kedua setelah al-Qur'an. Para ahli fiqih ketika menentukan aturan Islam, bila tidak menemukan penjelasan dari al-Qur'an dan tidak pula ditemukan penjelasan dari hadis, maka mereka menerapkan ijtihad, sebagai formulasi pemikiran dalam menjelaskan syariat Islam (Sy, 2017). Namun demikian, bila suatu perkara 
tidak ditemukan penjelasannya dari al-Qur'an, sebelum para ahli fiqih mengoptimalkan ijtihad, maka mereka lebih terpaku pada hadis (Hosen \& Musyafiq, n.d.). Kebutuhan para ahli fiqih terhadap hadis telah mendorong berkembangnya ilmu hadis (Rodliyana, 2012), khususnya metode syarah hadis (Jannah, 2017). Nanti di era kontemporer, analisis dari ilmu-ilmu sosial tampak meramaikan pendekatan penelitian hadis metode syarah (Sagir, 2017).

Mula-mula ilmu hadis seakan tidak dapat dipisahkan dari ilmu fiqih (Hosen \& Musyafiq, n.d.). Sebab, faktanya, di masa klasik, setiap ahli fiqih pasti ahli hadis (Rodliyana, 2012). Hal ini tidak dipungkiri karena puncak kejayaan Islam pada masa klasik disebut-sebut sebagai peradaban fiqih (Darmalaksana, 2004). Sehingga berbagai keilmuan Islam seakan direntang untuk kemajuan keilmuan fiqih (Rodliyana, 2012), terutama ilmu hadis. Akan tetapi, keberadaan hadis pada kenyataannya dibutuhkan oleh ilmu-ilmu keislaman lain. Secara interdisipliner, pembahasan hadis ditemukan dalam kajian ilmu tauhid, ilmu ahlak, dan sebagainya (Syafii, 2017). Interdisipliner ialah pengkajian bidang ilmu dengan pendekatan ilmu lain yang serumpun (Rohmatika, 2019). Rumpun keilmuan Islam meliputi filsafat Islam, ilmu tauhid, ilmu fiqih, ilmu ahlak, ilmu al-Qur'an, ilmu hadis, dan lain-lain. Dalam pengertian sekarang ini rumpun keilmuan Islam dikenal dengan filsafat Islam, teologi Islam, tasawuf (Raharusun, 2016), dan lain-lain (Bakri, 2016). Sejak di masa klasik, terutama di masa pertengahan Islam, dan hingga ke masa modern, disebut-sebut bahwa ilmu fiqih terlalu menghegemoni ilmu hadis (Rodliyana, 2012).

Pada era modern di abad ke 18 M. (Hardiyati, 2020), ilmu-ilmu sosial mengalami perkembangan di dunia Barat (Agus, 1999). Pada era modern di dunia Barat berlangsung renaissance yang berusaha mengembangan ilmu pengetahuan tidak dari postulat ilmu agama (Menčik, 2020), tetapi dari penalaran akal melalui pemikiran logis (Saifullah, 2014). Dari renaissance ini berkembanglah ilmu-ilmu pengetahuan sosial, seperti fenomenologi (Hasbiansyah, 2008), antropologi (Chaer, 2014), sosiologi (Lubis, 2017), psikologi, dan lain-lain (Maliki, 2018). Berikutnya, berkembang pesat sains dan teknologi (Ariyanto, 2018) dengan landasan empirisme, keilmuan objektif, observasi, dan validitas dalam kerangka filsafat ilmu Barat (Adib, 2011). Psikologi dikenal sebagai ilmu sosial yang mula pertama mengikuti pola penelitian saintifik (Effendy, 2009). Pada era kontemporer, perkembangan ilmu-ilmu sosial (Ramah, 2019) dan terlebih kemajuan pesat sains dan teknologi memberikan dampak metodologis terhadap keilmuan lainnya (Ibrahim et al., 2018), termasuk berdampak pada keilmuan Islam (Mahyudi, 2016).

Pada masa klasik telah berlangsung penelitian pendekatan interdisipliner ilmu hadis dengan rumpun ilmu-ilmu keislaman lain. Hal ini sebagaimana terlihat dalam penelitian dengan menggunakan metode syarah hadis (Zahrah, 2020). Antara lain timbul metode syarah hadis dengan penjelasan secara global (ijmali), sehingga melahirkan kitab-kitab syarah hadis yang memuat penjelasan hadis-hadis secara global pula (Muhtador, 2016). Timbul pula metode syarah hadis yang berusaha menjelaskan hadis secara kritis (tahlili), di mana hal ini melahirkan kitab-kitab spesifik dalam bentuk kitab fiqih, kitab tauhid, dan kitab ahlak (Muhtador, 2016). Selebihnya, muncul kitab-kitab komparatif yang dihasilkan dari penelitian hadis dengan metode syarah pendekatan muqaran (Muhtador, 2016). Sehingga pada dasarnya sejak di masa klasik Islam telah lazim dilakukan penelitian hadis dengan metode syarah melalui pendekatan interdisipliner dari ilmu-ilmu rumpun Islam.

Baru pada era modern, para tokoh intelektual muslim mulai mengarahkan penelitian Islam dengan pendekatan dari ilmu-ilmu yang berkembang di era modern. Di antaranya tokoh yang terkenal ialah, Fazlur Rahman, intelektual muslim asal Pakistan. Ia meluncurkan sejumlah gagasan, seperti Islam autentik (Panjwani, 2012), Islam dan modernitas (Rahman, 1984), tema-tema utama al-Qur'an (Rahman, 2009), dan lain-lain. Tokoh serupa ini di era modern menawarkan pengkajian teks Suci, al-Qur'an dan hadis, tidak secara tekstual tetapi kontekstual (Irawan, 2019). Praktis, penelitian hadis tidak cukup hanya pendekatan 
kebahasaan secara tekstual (Faiqoh, 2017), dan tidak cukup pula hanya menerapkan pendekatan sebab wurud al-hadits dalam penelitian kontekstual hadis (Aw, 2011), halnya juga kontekstualisasi al-Qur'an (Solahudin, 2016). Arahan dari tokoh-tokoh muslim kesarjanaan Barat modern (M. Zuhri, 2015) kenyataannya menghendaki penelitian hadis dianalisis dengan pendekatan ilmu kesejarahan (Rokhzi, 2015) dan ilmu-ilmu sosial lainnya (M. D. Huda, 2016). Arahan ini langsung ataupun tidak langsung telah mendorong pesatnya penelitian living hadis di Indonesia (Salleh et al., 2020). Sebuah metode penelitian yang berusaha menganalisis nilai-nilai hadis yang hidup dalam tradisi dan budaya masyarakat Islam (Darmalaksana et al., 2019) dengan pendekatan ilmu-ilmu sosial, seperti antropologi (umi Rosidah, 2011), sosiologi (Dewi, 2017), genealogi (Qudsy, 2016), dan lain-lain. Dewasa ini penelitian living hadis dengan pendekatan ilmu-ilmu sosial (M Alfatih Suryadilaga, 2006), bukan saja dilakukan pada penelitian disertasi jenjang doktor dan penelitian tesis jenjang magister, melainkan bahkan ramai diterapkan dalam penelitian skripsi jejang sarjana di kalangan peminat ilmu hadis (Darmalaksana et al., 2019).

Tidak heran bila kemudian ada kalangan peminat bidang hadis yang merasa khawatir tergerusnya metode syarah masa klasik dengan digunakannya secara maksimal pendekatan ilmu-ilmu sosial (Kurniati, 2020). Ada pula yang menilai penggunaan metode living hadis sebagai bentuk pergeseran ilmu hadis menuju liberalisasi pengetahuan Islam (Salleh et al., 2019). Di satu sisi pandangan semacam ini perlu mendapat respon dalam mendudukan penelitian hadis secara proporsional, dan disi lain perlu dilakukan pembahasan prinsip serta operasional metode syarah hadis dengan pendekatan ilmu-ilmu sosial dalam pengembangan ilmu hadis. Pastinya, melalui penelitian hadis metode syarah inilah analisis dengan pendekatan ilmu-ilmu sosial terbuka pintunya.

\section{Penelitian Metode Syarah Hadis Pendekatan Ilmu Sosial}

Hadis merupakan subjek penelitian ilmu hadis. Sebagai ilmu yang dituntut untuk berkembang seusai dengan kemajuan zamannya (Bistara, 2020), ilmu hadis telah dikembangkan mulai dari takhrij hadis (Qomarullah, 2016), syarah hadis (Jannah, 2017), dan kemudian syarah hadis dengan analisis dari pendekatan berbagai ilmu (Hariono, 2019), baik interdisipliner maupun multidisipliner (Taufik, 2020b). Secara interdisipliner, hadis diteliti dengan pendekatan rumpun ilmu-ilmu keislaman, seperti filsafat Islam, teologi Islam, tasawuf, dan syariat Islam (Arifin, 2014). Secara multidisipliner, hadis mulai diteliti dengan menerapkan analisis dari pendekatan ilmu-ilmu sosial, seperti antropologi (Rohmana, 2015), sosiologi (Assagaf, 2015), genealogi (Qudsy, 2016), dan lain-lain. Bahkan, arah kebijakan menetapkan mandat integrasi ilmu (Tim Penyusun, 2019b), berarti hal ini menghendaki integrasi ilmu hadis dengan ilmu-ilmu umum (Afwadzi, 2017). Semua ini pada dasarnya sangat mungkin dilakukan ketika hadis dipandang sebagai subjek penelitian dalam upaya pengembangan ilmu hadis (Darmalaksana, 2020e).

Jika materi ilmu dipetakan ke dalam materi dasar dan materi terapan (Bentley et al., 2015), ilmu hadis pada dasarnya merupakan khazanah keilmuan Islam kategori materi dasar. Secara garis besar, tuntutan penelitian materi dasar terbagi tiga, yaitu menjelaskan, menganalisis, dan melahirkan postulat baru (Tim Penyusun, 2019a). Upaya menjelaskan diarahkan untuk penelitian skripsi untuk jenjang sarjana bidang ilmu dasar. Analisis diarahkan untuk penelitian tesis jenjang magister bidang ilmu dasar. Adapun penemuan postulat baru diarahkan untuk penelitian disertasi jenjang doktor bidang ilmu dasar. Akan tetapi, kebijakan mengarahkan agar materi dasar ilmu-ilmu keislaman diupayakan mampu merambah ke penerapan (Tim Penyusun, 2018c). Secara garis besar, tuntutan penelitian materi terapan dibagi tiga, yakni indentifikasi masalah, pembentukan model penyelesaian masalah, dan solusi permasalahan (Tim Penyusun, 2019a). Identifikasi masalah diarahkan untuk penelitian skripsi jenjang sarjana bidang ilmu terapan. Pembentukan model untuk penyelesaian masalah diarahkan untuk 
penelitian tesis jenjang magister bidang ilmu terapan. Terakhir, solusi atas permasalahan diarahkan untuk penelitian disertasi jenjang doktor bidang ilmu terapan.

Arah kebijakan di pendidikan tinggi Islam telah menetapkan pengaturan (regulation) untuk lulusan jenjang sarjana, magister, dan doktor bidang ilmu hadis. Jenjang sarjana diarahkan mampu menjelaskan makna dari kandungan hadis (Tim Penyusun, 2018a). Jenjang magister diarahkan untuk mampu melakukan penelitian hadis dengan pendekatan interdisipliner (Tim Penyusun, 2018b). Adapun jenjang doktor diarahkan untuk mampu melakukan penelitian hadis dengan pendekatan transdisipliner (Tim Penyusun, 2018b). Dengan demikian, pada dasarnya penjelasan hadis dengan analisis melalui pendekatan ilmu-ilmu sosial belumlah ditekankan bagi jenjang sarjana dalam penelitian skripsi. Sebab, jenjang sarjana dipandang belum mumpuni dari teori-teori ilmu sosial untuk dijadikan analisis dan pendekatan dalam syarah hadis. Dalam hal ini, jenjang sarjana lebih diarahkan untuk menerapkan metode syarah hadis dengan pendekatan dari masa klasik, seperti ijmali, tahlili, dan muqaran (Kurniati, 2020). Sedangkan jenjang magister pada penelitian tesis telah diarahkan untuk mampu melakukan penelitian hadis dengan pendekatan dari ilmu-ilmu Islam yang serumpun dan sekaligus dari pendekatan ilmu-ilmu lain meskipun tidak serumpun (M Alfatih Suryadilaga, 2007), yang dalam hal ini ilmu-ilmu sosial (M Alfatih Suryadilaga, 2006), dan bahkan, pendekatan sains dan teknologi (Ismail, 2016). Adapun jenjang doktor untuk penelitian disertasi telah diarahkan untuk mampu melakukan integrasi ilmu antara ilmu hadis dan ilmu umum (Firdaus \& Suryadilaga, 2019), sebagai upaya mengakhiri dikotomi ilmu (Bisryi, 2009).

Belum dibebankannya pendekatan ilmu-ilmu sosial dalam penelitian skripsi, maka kebijakan ini merupakan hal yang logis. Pertama, jenjang sarjana belum menguasai ilmu-ilmu sosial untuk dijadikan analisis dan pendekatan dalam penelitian hadis. Kedua, jenjang sarjana lebih diarahkan untuk menguasai metode-metode syarah dari era klasik dalam penelitian hadis (Kurniati, 2020). Ketiga, penerapan analisis dari pendekatan ilmu-ilmu sosial secara sekaligus dengan penerapan metode-metode syarah dari era klasik Islam pada penelitian skripsi bisa mengakibatkan hasil penelitian yang setengah-setengah. Padahal, keutuhan dan kedalaman metode-metode dari masa klasik Islam sangat dibutuhkan di satu sisi (Abbas, 2019), dan ketajaman analisis melalui pendekatan ilmu-ilmu sosial merupakan kebutuhan pula di sisi lain (Anggoro, 2019). Sehingga dibutuhkan rekonstruksi pendekatan dari metode-metode syarah hadis masa klasik untuk penelitian skripsi (Salleh et al., 2019).

Berbeda dengan penelitian skripsi, penelitian tesis dan disertasi justru diarahkan untuk mampu menerapkan penelitian hadis dengan analisis dari pendekatan ilmu-ilmu lain. Hal ini karena bagi jenjang magister dan doktor telah disajikan teori-teori dari berbagai ilmu, khususnya teori ilmu-ilmu sosial. Tentu penyajian teori-teori ini dimaksudkan agar jenjang magister dan doktor bidang ilmu hadis dituntut mampu menguasai teori-teori ilmu bidang lain (Muhsin, 2015) yang pada gilirannya mampu menerapakan pendekatan multidisipliner pada tesis, dan pendekatan transdisipliner pada penelitian disertasi (Afwadzi, 2017). Selebihnya, peminat ilmu hadis jenjang magister diarahkan mampu merambah penelitian terapan untuk melakukan identifikasi masalah dan sekaligus pembuatan model untuk antisipasi masalah. Selebihnya lagi, peminat ilmu hadis jenjang doktor diarahkan selain mampu menghasilkan postulat baru di bidang materi dasar, juga diarahkan untuk mampu menemukan solusi permasalahan sebagai konsekuensi dari penerapan ilmu pengetahuan dalam kerangka integrasi ilmu, termasuk ilmu hadis (Lukman, 2017).

Penguatan analisis dalam penelitian hadis metode syarah dengan pendekatan ilmu-ilmu sosial dipastikan dapat menguatkan masa depan penelitian hadis (Abbas, 2019) di Nusantara (Wahid, 2017). Pendidikan tinggi Islam dapat berperan proporsional (Wahid \& Masri, 2018) dalam menyikapi ragam penelitian hadis (Muhammad Alfatih Suryadilaga, 2015), pola penelitian hadis (Adriansyah, 2018), dan 


\section{Khazanah Sosial, Vol. 2 No. 3 155-166}

Studi Penggunaan Analisis Pendekatan Ilmu-ilmu Sosial dalam Penelitian Hadis Metode Syarah Wahyudin Darmalaksana

orientasi penelitian hadis (N. Huda \& Pahrudin, 2018) melalui rencana implementasi penelitian hadis pada jenjang sarjana, magister, dan doktor (Darmalaksana, 2020e). Jurusan Ilmu Hadis (Muhammad Alfatih Suryadilaga, 2016) berperan sentral dalam pengembangan ilmu hadis melalui penelitian hadis dengan menggunakan analisis dalam metode syarah dari pendekatan ilmu-ilmu sosial.

\section{SIMPULAN}

Penelitian hadis dengan menerapkan analisis dari pendekatan ilmu-ilmu sosial merupakan subjek yang sangat diarahkan dalam kebijakan pengembangan keilmuan Islam pada pendidikan tinggi keagamaan Islam di Indonesia. Analisis dari pendekatan ilmu-ilmu sosial sangat terbuka lebar peluangnya dalam penelitian hadis metode syarah. Hanya saja hal ini belum dibebankan pada penelitian skripsi jenjang sarjana, sebab mereka dipandang belum mumpuni dalam penguasaan teori-teori ilmu sosial. Sebaliknya, pendekatan ilmu-ilmu sosial sangat ditekankan bagi penelitian tesis dan disertasi. Jenjang magister dan doktor bidang ilmu hadis telah diarahkan penguasaan teori-teori berbagai ilmu untuk dijadikan analisis dan pendekatan dalam penelitian hadis. Bahkan, jejang doktor bidang ilmu hadis diarahkan mampu melakukan integrasi ilmu dalam penelitian hadis, baik ilmu-ilmu sosial maupun sains dan teknologi. Penelitian ini diharapkan memiliki implikasi manfaat khususnya bagi para peminat bidang ilmu hadis dalam pelaksanaan penelitian hadis melalui metode syarah dengan menggunakan analisis dari pendekatan ilmu-ilmu sosial, seperti antropologi, sosiologi, dan arkeologi. Penelitian ini memiliki keterbatasan hanya membahas penerapan analisis dari pendekatan ilmu-ilmu sosial dalam penelitian hadis dengan metode syarah, sehingga perlu dilakukan penelitian lebih luas lagi dalam optimalisasi penerapan ilmu-ilmu sosial pada keilmuan hadis. Penelitian ini merekomendasikan untuk perumusan model analisis dari pendekatan ilmu-ilmu sosial dalam penelitian hadis melalui asosiasi ilmu hadis Indonesia.

\section{DAFTAR PUSTAKA}

Abbas, N. (2019). Masa Depan Hadis Dan 'Ulum Al-Hadis (Suatu Gagasan Ke Arah Pembaruan Pemikiran Hadis). Sulesana: Jurnal Wawasan Keislaman, 13(1), 41-63.

Adib, H. M. (2011). Filsafat Ilmu: Ontologi, Epistemol ogi, Aksiologi, dan Logika Ilmu Pengetahuan. Pustaka Pelajar.

Adibah, I. Z. (2017). Pendekatan Sosiologis Dalam Studi Islam. INSPIRASI: Jurnal Kajian Dan Penelitian Pendidikan Islam, 1(1), 1-20.

Adriansyah, N. Z. (2018). Pola Kajian Hadis Akademik Di Perguruan Tinggi Keagamaan Islam Negeri (PTKIN) Di Indonesia (Studi Skripsi Mahasiswa Tafsir Hadis UIN Raden Fatah Palembang, UIN Syarif Kasim Pekanbaru dan UIN Imam Bonjol Padang). Jurnal Ilmu Agama: Mengkaji Doktrin, Pemikiran, Dan Fenomena Agama, 19(2), 177-195.

Afwadzi, B. (2016). Membangun Integrasi Ilmu-Ilmu Sosial dan Hadis Nabi. Jurnal Living Hadis, 1(1), 101-128.

Afwadzi, B. (2017). Integrasi ilmu-ilmu alam dan ilmu-ilmu sosial dengan pemahaman hadis Nabi: Telaah atas konsepsi, aplikasi, dan implikasi. Theologia, 28(2), 351-390.

Agus, B. (1999). Pengembangan ilmu-ilmu sosial: studi banding antara pandangan ilmiah dan ajaran Islam. Gema Insani.

Andariati, L. (2020). Hadis dan Sejarah Perkembangannya. Diroyah: Jurnal Studi Ilmu Hadis, 4(2).

Anggoro, T. (2019). Perkembangan Pemahaman Hadis Di Indonesia: Analisis Pergeseran Dan Tawaran Di Masa Kini. Diya Al-Afkar: Jurnal Studi Al-Quran Dan Al-Hadis, 7(01), 147-166.

Anshori, M. (2017). Syarh Hadis dari Masa Ke Masa. Jurnal Al-Irfani: Jurnal Kajian Tafsir Hadits, 3(1), $1-32$.

Arifin, J. (2014). Pendekatan Ulama Hadis dan Ulama Fiqh dalam Menelaah Kontroversial Hadis. Jurnal Ushuluddin, 22(2), 145-154. 
Ariyanto, D. A. S. (2018). Sains dan teknologi dalam perkembangan peradaban manusia. Seminar Nasional Pendidikan Teknik Otomotif.

Assagaf, J. (2015). Studi Hadis Dengan Pendekatan Sosiologis: Paradigma Living-Hadis. Holistic AlHadis, 1(2), 289-316.

Aw, L. C. (2011). Memahami Makna Hadis Secara Tekstual Dan Kontekstual. Ulumuna, 15(2), 391414.

Bahammam, F. S. (2013). Fiqih Modern Praktis. Gramedia Pustaka Utama.

Bakri, S. (2016). Tarikh Islam: Transformasi Teologi dalam Lintasan Sejarah Peradaban. BukukuMedia.

Bentley, P. J., Gulbrandsen, M., \& Kyvik, S. (2015). The relationship between basic and applied research in universities. Higher Education, 70(4), 689-709.

Bisryi, H. (2009). Mengakhiri Dikotomi Ilmu Dalam Dunia Pendidikan. Edukasia Islamika, 7(2), 70254.

Bistara, R. (2020). Perkembangan Ilmu Hadis Periode Keempat Dan Kelima. KACA (Karunia Cahaya Allah): Jurnal Dialogis Ilmu Ushuluddin, 10(1), 108-120.

Burhanuddin, B. (2018). Metode dalam memahami Hadis. Jurnal Al-Mubarak: Jurnal Kajian AlQur'an Dan Tafsir, 3(1), 1-11.

Chaer, M. T. (2014). Pendekatan Antropologi Dalam Studi Agama. At-Tahdzib: Jurnal Studi Islam Dan Muamalah, 2(2), 114-132.

Darmalaksana, W. (2004). Hadis di Mata Orientalis: Telaah atas Pandangan Ignaz Goldziher dan Joseph Schacht. Bandung: Benang Merah Press.

Darmalaksana, W. (2020a). Formula Penelitian Pengalaman Kelas Menulis. Jurnal Kelas Menulis UIN Sunan Gunung Djati Bandung.

Darmalaksana, W. (2020b). Living Hadis Nilai-nilai Inti Manajemen Strategis Pendidikan Tinggi. Jurnal Ushuluddin UIN Sunan Gunung Djati Bandung, 2.

Darmalaksana, W. (2020c). Metode Penelitian Kualitatif Studi Pustaka dan Studi Lapangan. PrePrint Digital Library UIN Sunan Gunung Djati Bandung.

Darmalaksana, W. (2020d). Prosiding Proses Bisnis Validitas Hadis untuk Perancangan Aplikasi Metode Tahrij. Jurnal Ushuluddin UIN Sunan Gunung Djati Bandung, 1, 1-7.

Darmalaksana, W. (2020e). Rencana Implementasi Penelitian Hadis pada Pendidikan Tinggi Indonesia: Sebuah Analisis Kebijakan. Jurnal Hadis Fakultas Ushuluddin UIN Sunan Gunung Djati Bandung.

Darmalaksana, W., Alawiah, N., Thoyib, E. H., Sadi'ah, S., \& Ismail, E. (2019). Analisis Perkembangan Penelitian Living Al-Qur'an dan Hadis. Jurnal Perspektif, 3(2), 134-144.

Darmalaksana, W., Pahala, L., \& Soetari, E. (2017). Kontroversi Hadis sebagai Sumber Hukum Islam. Wawasan: Jurnal Ilmiah Agama Dan Sosial Budaya, 2(2), 245-258.

Dewi, S. K. (2017). Fungsi Performatif dan Informatif Living Hadis dalam Perspektif Sosiologi Reflektif. Jurnal Living Hadis, 2(2), 179-207.

Effendy, N. (2009). Perkembangan psikologi: Kelahiran integral. Anima, 24 (2), 124-131.

Faiqoh, L. (2017). Hermeneutika Otentisitas Hadis M. Mustofa Azami. Farabi: Journal of Ushuluddin \& Islamic Thought, 14(1).

Firdaus, M. T., \& Suryadilaga, M. A. (2019). Integrasi Keilmuan Dalam Kritik Matan Hadis. TAJDID: Jurnal Ilmu Ushuluddin, 18(2), 153-176.

Hardiyati, M. (2020). Sejarah Perkembangan Ilmu Dunia Barat. Prosiding Konferensi Integrasi Interkoneksi Islam Dan Sains, 2, 11-16.

Hariono, D. (2019). Syarah Hadis: Model dan Aplikasi Metodologis. UNIVERSUM: Jurnal KeIslaman Dan Kebudayaan, 13(2).

Hasbiansyah, 0. (2008). Pendekatan fenomenologi: Pengantar praktik penelitian dalam Ilmu Sosial dan Komunikasi. Mediator: Jurnal Komunikasi, 9(1), 163-180. 
Hosen, M., \& Musyafiq, A. (n.d.). Urgensi Integrasi Antara Ahli Fiqh dan Ahli Hadis dalam Memahami Sunah: Studi atas Pemikiran Syekh Muhammad al-Ghazali dalam Karyanya al-Sunah alNabawiyah baina Ahl al-Fiqh wa Ahl al-Hadis.

Hsieh, H.-F., \& Shannon, S. E. (2005). Three approaches to qualitative content analysis. Qualitative Health Research, 15(9), 1277-1288.

Huda, M. D. (2016). Pendekatan antropologis dalam studi islam. Didaktika Religia, 4(2), 139-162.

Huda, N., \& Pahrudin, A. (2018). Orientasi Kajian Hadis Kontemporer Indonesia (Studi Artikel EJurnal Dalam Portal Moraref 2015-2017). Refleksi, 17(2), 169-192.

Husnaini, A. (n.d.). Ulumul Hadis dan Sejarah Perkembangannya.

Ibrahim, M. I., Nazri, F. I., Basiron, B., Baharuddin, A., Bidang, M., Persepsi, K., \& Bentong, S. I. (2018). Islam serta pembentukan sains dan teknologi. Prosiding Seminar Tamadun Islam UTM, 1-2.

Irawan, R. (2019). Metode Kontekstual Penafsiran Al-Qur'an Perspektif Fazlur Rahman. Al-Dzikra: Jurnal Studi Ilmu Al-Qur'an Dan Al-Hadits, 13(2), 171-194.

Ismail, M. Y. (2016). Peranan Sains Moden dalam Interaksi teks Hadis: Penelitian Terhadap Hadis Berkaitan Penciptaan Janin Manusia.

Jannah, D. (2017). Kritik dan Syarah Hadits. Al-Tarbawi Al-Haditsah: Jurnal Pendidikan Islam, 2(1).

Kurniati, Y. (2020). Rekonstruksi Metodologi Keilmuan Syarah Hadis Klasik. Islam Transformatif: Journal of Islamic Studies, 4(1), 46-56.

Lubis, H. M. R. (2017). Sosiologi Agama: Memahami Perkembangan Agama dalam Interaksi Islam. Kencana.

Lukman, F. (2017). Integrasi-Interkoneksi dalam Studi Hadis Disertasi Di Uin Sunan Kalijaga Yogyakarta. RELIGIA, 1-11.

Mahyudi, D. (2016). Pendekatan Antropologi Dan Sosiologi Dalam Studi Islam. Ihya Al-Arabiyah: Jurnal Pendidikan Bahasa Dan Sastra Arab, 2(2).

Maliki, Z. (2018). Rekontruksi Teori Sosial Modern. UGM PRESS.

Mardiana, D., \& Darmalaksana, W. (2020). Relevansi Syahid Ma'nawi dengan Peristiwa Pandemic Covid-19: Studi Matan Pendekatan Ma'anil Hadis. Jurnal Perspektif, 4(1), 12-19.

Menčik, D. (2020). Perspectivism of Renaisance Thought. Doi: Http://Dx. Doi. Org/10.12681/Eml, 22101.

Muhsin, M. (2015). Memahami Hadis Nabi dalam Konteks Kekinian: Studi Living-Hadis. Holistic AlHadis, 1(1), 1-24.

Muhtador, M. (2016). Sejarah Perkembangan Metode dan Pendekatan Syarah Hadis. Riwayah, 2(2), 259-272.

Muin, M. (2015). Pemahaman Komprehensif Hadis Melalui Asbab Al-Wurud. Addin, 7(2).

Musa, A. Y. (2010). Hadith as scripture: discussions on the authority of prophetic traditions in Islam. AMERICAN JOURNAL OF ISLAMIC SOCIAL SCIENCES 27: 1, 132.

Nufus, A. H. (2018). Pengantar dan Sejarah Perkembangan Ilmu Hadits.

Panjwani, F. (2012). Fazlur Rahman and the search for authentic Islamic education: A critical appreciation. Curriculum Inquiry, 42(1), 33-55.

Qomarullah, M. (2016). Metode Takhrij Hadits Dalam Menakar Hadits Nabi. EL-Ghiroh, 11(2), 2334.

Qudsy, S. Z. (2016). Living Hadis: Genealogi, Teori, dan Aplikasi. Jurnal Living Hadis, 1(1), 177-196.

Raharusun, A. S. (2016). Tasawuf Nabawi: Membaca Maqom Rido Dalam Hadis Nabi. Syifa Al-Qulub, 1(1), 99-112.

Rahman, F. (1984). Islam and modernity: Transformation of an intellectual tradition (Vol. 15). University of Chicago Press.

Rahman, F. (2009). Major Themes of the Qur'an. University of Chicago Press.

Ramah, M. (2019). Wacana dalam Perkembangan Ilmu Sosial Modern. KINESIK, 6(2), 165-175.

Rodliyana, M. D. (2012). Hegemoni Fiqh Terhadap Penulisan Kitab Hadith. JOURNAL OF QUR'AN AND HADITH STUDIES, 1(1), 119-144. 


\section{Khazanah Sosial, Vol. 2 No. 3 155-166}

Studi Penggunaan Analisis Pendekatan Ilmu-ilmu Sosial dalam Penelitian Hadis Metode Syarah Wahyudin Darmalaksana

Rohmana, J. A. (2015). Pendekatan Antropologi Dalam Studi Living Hadis Di Indonesia: Sebuah Kajian Awal. Holistic Al-Hadis, 1(2), 247-288.

Rohmatika, R. V. (2019). Pendekatan Interdisipliner dan Multidisipliner Dalam Studi Islam. AlAdyan: Jurnal Studi Lintas Agama, 14(1), 115-132.

Rokhzi, M. F. (2015). Pendekatan Sejarah dalam Studi Islam. MODELING: Jurnal Program Studi PGMI, 2(1), 85-94.

Sagir, A. (2017). Perkembangan Syarah Hadis dalam Tradisi Keilmuan Islam. Jurnal Ilmiah Ilmu Ushuluddin, 9(2), 129-151.

Saifullah, S. (2014). Renaissance dan Humanisme Sebagai Jembatan Lahirnya Filsafat Modern. Jurnal Ushuluddin, 22(2), 133-144.

Salleh, N. M., Shamsu, L. S. H., Wazir, R., Usman, A. H., Abdullah, M. F. R., Ismail, A. Z., \& Burhanuddin, N. A. (2019). Penyalahgunaan Living Hadis dalam Kalangan Kelompok Liberal: Satu Sorotan Literatur Secara Sistematik. HADIS, 9(17), 65-78.

Salleh, N. M., Usman, A. H., Wazir, R., Shamsu, L. S. H., \& Burhanuddin, N. A. (2020). Living Sunnah Menurut Fazlur Rahman: Satu Sorotan Literatur Secara Sistematik. AL-BURHĀN: JOURNAL OF QUR'ĀN AND SUNNAH STUDIES, 4(1), 127-141.

Santosa, S. (2016). Melacak Jejak Pensyarahan Kitab Hadis. Diroyah: Jurnal Ilmu Hadis, 1(1).

Soetari, E. (1994). Ilmu Hadits. Amal Bakti Press.

Soetari, E. (2005). Ilmu Hadits: Kajian Riwayah dan Dirayah. Mimbar Pustaka.

Soetari, E. (2015). Syarah dan Kritik Hadis dengan Metode Tahrij: Teori dan Aplikasi (2nd ed.). Yayasan Amal Bakti Gombong Layang.

Solahudin, M. (2016). Pendekatan Tekstual dan Kontekstual dalam Penafsiran Alquran. Al-Bayan: Jurnal Studi Ilmu Al-Qur'an Dan Tafsir, 1(2), 115-130.

Sulaemang, S. L. (2016). Teknik Interpretasi Hadis dalam Kitab Syarah Al-Hadis. Jurnal Ilmiah Ilmu Ushuluddin, 14(2), 125-132.

Sumarna, E. (2016). Syarah Hadis dalam Perspektif Kritik Dakhili dan Khariji (Menuju Pemaknaan Hadis yang Integritas). Jurnal Pendidikan Agama Islam-Ta'lim, 14(2), 157-164.

Suryadilaga, M Alfatih. (2006). Living Hadis dalam Kerangka Dasar Keilmuan UIN Sunan Kalijaga. Yogyakarta: DIPA UIN Sunan Kalijaga.

Suryadilaga, M Alfatih. (2007). Implementasi Pendekatan Integrasi-Interkoneksi dalam Kajian Living Hadis. Islamic Studies dalam Paradigma Integrasi-Interkoneksi: Sebuah Antologi ....

Suryadilaga, Muhammad Alfatih. (2015). Ragam Studi Hadis di PTKIN Indonesia dan Karakteristiknya: Studi atas Kurikulum IAIN Bukittinggi, IAIN Batusangkar, UIN Sunan Kalijaga, dan IAIN Jember. JOURNAL OF QUR'AN AND HADITH STUDIES, 4(2), 215-247.

Suryadilaga, Muhammad Alfatih. (2016). Profil Prodi Ilmu Hadis di Era Globalisasi Teknologi Informasi. Riwayah, 2(1), 114-131.

Sy, S. (2017). Pengaruh Hadis Dalam Ilmu Fiqih dan Teologi (Kajian Tokoh dan Pemikiran Imam Syafii). El-Furqania: Jurnal Ushuluddin Dan Ilmu-Ilmu Keislaman, 3(02), 221-233.

Syafii, S. (2017). Dari ilmu tauhid/ilmu kalam ke teologi: analisis epistemologis. Jurnal Theologia, 23(1), 1-15.

Taufik, E. T. (2020a). Epistemologi Syarah Hadis di Perguruan Tinggi: Diskursus Genealogis Terhadap Transmisi dan Transformasi Metode Syarah Hadis di Indonesia. Ushuluna: Jurnal Ilmu Ushuluddin, 6(2), 33-50.

Taufik, E. T. (2020b). Syarah Hadis Di Perguruan Tinggi: Genealogis Transmisi Dan Transformasi Metode Syarah Hadis Di Indonesia. Ushuluna: Jurnal Ilmu Ushuluddin, 6(2), 33-50.

Thantowi, M. R. (1994). Fungsi al-qur'an dan as sunnah sebagai petunjuk bagi manusia. IAIN Sunan Ampel Surabaya.

Tim Penyusun. (2018a). Keputusan Direktur Jenderal Pendidikan Islam Nomor 2500 Tahun 2018 tentang Standar Kompetensi Lulusan dan Capaian Pembelajaran Lulusan Program Studi Jenjang Sarjana pada PTKI. 


\section{Khazanah Sosial, Vol. 2 No. 3 155-166}

Studi Penggunaan Analisis Pendekatan Ilmu-ilmu Sosial dalam Penelitian Hadis Metode Syarah Wahyudin Darmalaksana

Tim Penyusun. (2018b). Keputusan Direktur Jenderal Pendidikan Islam Nomor 6165 Tahun 2018 tentang Standar Kompetensi Lulusan dan Capaian Pembelajaran Lulusan Program Studi Jenjang Magister dan Doktor pada PTKI.

Tim Penyusun. (2018c). Keputusan Direktur Jenderal Pendidikan Islam Nomor 6994 Tahun 2018 tentang Agenda Riset Keagamaan Nasional (Arkan) 2018-2028.

Tim Penyusun. (2019a). Keputusan Direktur Jenderal Pendidikan Islam Nomor 102 Tahun 2019 tentang Standar Keagamaan Pendidikan Tinggi Keagamaan Islam.

Tim Penyusun. (2019b). Keputusan Direktur Jenderal Pendidikan Islam Nomor 2498 Tahun 2019 tentang Pedoman Implementasi Integrasi Ilmu di PTKI.

umi Rosidah, F. (2011). Pendekatan Antropologi dalam Studi Agama. Religio: Jurnal Studi AgamaAgama, 1(1), 23-32.

Wahid, R. A. (2017). Masa depan perkembangan kajian hadis di nusantara. Kertas Dibentangkan, Anjuran Kolej Universiti Islam Antarabangsa Selangor, 15.

Wahid, R. A., \& Masri, D. (2018). Perkembangan Terkini Studi Hadis Di Indonesia: Peran LembagaLembaga Pendidikan dalam Pengkajian Hadis.

Wahid, R. A., \& Masri, D. (2019). Perkembangan Terkini Studi Hadis di Indonesia. MIQOT: Jurnal Ilmu-Ilmu Keislaman, 42(2), 263-280.

Wazna, R. (2018). Metode Kontemporer Menggali Otentisitas Hadis (Kajian Pemikiran Harald Motzki). Jurnal Ilmiah Ilmu Ushuluddin, 17(2), 112-125.

Wendry, N., Anshori, M., Majid, A., M Dalil, F. Y., \& Rahman, H. (2018). Paradigma Studi Hadis Kontemporer.

Zahrah, N. S. (2020). Gharib al-Hadits Sebagai Embriologi Syarah Hadits dan Transformasinya. ElAfkar: Jurnal Pemikiran Keislaman Dan Tafsir Hadis, 9(1), 127-141.

Zuhri, M. (2015). Perkembangan Kajian Hadis Kesarjanaan Barat. ULUL ALBAB Jurnal Studi Islam, $16(2), 215-234$.

Zuhri, S., \& Dewi, S. K. (2018). Living Hadis; Praktik, Resepsi, Teks, dan Transmisi. Yogyakarta: QMedia. 